\title{
Effect of fatty acid calcium salts from linseed oil on the yield and n-3 fatty acid content of milk and on blood plasma parameters of cows
}

\author{
F. Brzóska1 \\ National Research Institute of Animal Production \\ Krakowska 1, 32-083 Balice, Poland
}

(Received 23 December 2005; revised version 25 April 2006; accepted 5 July 2006)

\begin{abstract}
The study was carried out with 16 Red-and-White cows in a $4 \times 4$ Latin square design. In 4 periods of 21 days each, diets containing grass silage, maize silage, brewers grains and concentrate mixture containing calcium salts of fatty acids (CSFA) were given to cows at a rate of $0.28 \mathrm{~kg} / \mathrm{kg}$ of milk obtained. Cows received CSFA at $0,1.84,3.54$ or $5.40 \%$ of ration dry matter, which corresponded to $0,316,614$ or $940 \mathrm{~g}$ of CSFA per day. The average milk yield of the cows was $27.2 \pm 0.55$ $\mathrm{kg}$ /day and did not differ significantly between the groups. Feeding cows the CSFA supplement significantly increased the fat content of milk and daily fat production, while significantly reducing the protein content in milk and daily protein production, but significantly decreased the N-total, $\mathrm{N}$-protein and $\mathrm{N}$-casein contents of milk. The levels of stearic $\left(\mathrm{C}_{18: 0}\right)$, oleic $\left(\mathrm{C}_{18: 0}\right)$ and $\alpha$-linolenic $\left(\mathrm{C}_{18: 3}\right)$ acids significantly increased, the level of myristic $\left(\mathrm{C}_{14: 0}\right)$ and palmitic acids $\left(\mathrm{C}_{16: 0}\right)$ in milk significantly decreased. The differences in the levels of unsaturated fatty acids (UFA) in milk were significant $(23.91,27.31,31.92$ and $36.21 \mathrm{~g} / 100 \mathrm{~g}$ of fatty acids in the respective groups). The level of monounsaturated (MUFA) and polyunsaturated (PUFA) acids in milk significantly increased. The level of n-3 PUFA in milk increased from 1.20 to $2.25 \mathrm{~g} / 100 \mathrm{~g}$ of fatty acids, which corresponded to an increase in synthesis from 9.6 to $20.1 \mathrm{~g}$ acids/day. CSFA significantly reduced the n-6 PUFA-to-n-3 PUFA ratio from 3.5 to $2.2(\mathrm{P}<0.05)$. CSFA from linseed oil significantly increased the level of hypocholesterolemic acids (DFA) in milk (31.83, 36.31, 43.33 and 48.71 $\mathrm{g} / 100 \mathrm{~g}$ of fatty acids, respectively). The plasma concentration of total cholesterol and high-density lipoproteins decreased significantly under the influence of increasing CSFA doses.
\end{abstract}

KEY WORDS: linseed oil, CSFA, cows, milk production, fat, protein, fatty acids

\footnotetext{
${ }^{1}$ Corresponding author: e-mail: fbrzoska@izoo.krakow.pl
} 


\section{INTRODUCTION}

Linoleic (LA) and (LNA) $\alpha$-linoleic acid are not synthesized by humans and have to be obtained from the diet, preferably from milk products. Unlike the Mediterranean diet, the diet of people in industrialized countries has been found to be deficient in n-3 fatty acids, resulting in increased incidence of coronary atherosclerosis, cardiovascular diseases and coronary thrombosis (Givens et al., 2000). Consumption of fish and seafood, which are rich in n-3 acids, is limited. Efforts are therefore being made to increase the level of unsaturated fatty acids in animal products, including eggs, meat and cow's milk. Thanks to their higher melting temperature, CSFA used in cow nutrition do not disturb digestion or microbiological protein synthesis in the rumen, unlike increased amounts of vegetable oils and fish oil when given to cows. It has been shown that $n-3$ fatty acids, including $\alpha$-linolenic acid, are desaturated and elongated in the human body to eicosapentaenoic acid (EPA), which after further metabolic changes is a precursor of prostaglandins and other anti-inflammatory and antithrombotic substances that affect blood vessels (Bartnikowska and Kulasek, 1994).

In an earlier study, cows were fed CSFA obtained from $50 \%$ technical fat of animal origin and $50 \%$ linseed oil, with a small supplement of fish oil (Brzóska et al., 1999). The ban on the use of animal fats in feeding cattle encouraged us to investigate feeding cows CSFA obtained from linseed oil only. As a result, the obtained CSFA have a high concentration of $n-3$ fatty acids, which may prove useful for modifying the fatty acid composition of cow's milk.

It was hypothesized that giving cows CSFA obtained from linseed oil only, characterized by extremely limited rumen degradation and a high level of $n-3$ fatty acids, would increase the level of UFA, including n-3 acids, in milk, and thus improve its dietary value. The aim of the study was to verify this hypothesis in the first and second trimester of lactation in cows.

\section{MATERIAL AND METHODS}

In the experiment, lasting 84 days with 4 periods of 21 days each, 16 Red-andWhite cows were divided into 4 groups in a $4 \times 4$ Latin square design. Each period consisted of 18 pre-treatment and 3 treatment days, which were combined with milk recording and sample collection. Experimental animals were selected from a herd of 120 cows with an average milk yield of $6.500-7.000 \mathrm{~kg}$ in the last lactation. Cows were kept tethered indoors on rubber mats without litter. Cows had similar milk yields and were between day 50 and 120 of lactation, and were fed according to the INRA system. The ration contained wilted grass silage, maize silage, brewer's grain, and concentrate mixture (Table 1). The experimental factor was four different 
amounts of CSFA (INNFOSS Ltd., Poznań, Poland) obtained from linseed oil compared with the control group. The diet contained salts at $0.0,1.84,3.54$ or $5.40 \%$ of dry matter, which corresponded to an intake of $0,316,614$ or $940 \mathrm{~g}$ of CSFA/day, respectively. The feed was given to cows at $0.28 \mathrm{~kg} / \mathrm{kg}$ of milk obtained, in two equal doses, during the morning (6.00-7.00 a.m.) and evening (6.00-7.00 p.m.) milkings. Feed consumption was checked at the end of each period.

Grass and maize silage was given after the morning milking; brewers grains, in the afternoon $3 \mathrm{~h}$ before the evening milking. Pasture grass forage (orchard grass, meadow fescue and perennial ryegrass) for silage was cut in the heading stage. Maize for silage was harvested at the dough stage of maturity using a Claas Jaguar chopper with a pick-up attachment for high-stemmed plants, equipped with a grain crusher.

Table 1. Ingredients and chemical composition of diet, \% DM

\begin{tabular}{|c|c|c|c|c|}
\hline \multirow{2}{*}{ Indices } & \multicolumn{4}{|c|}{ Ca-FA salts, $\%$ diet DM } \\
\hline & 0.0 & 1.84 & 3.54 & 5.40 \\
\hline \multicolumn{5}{|l|}{ Diet ingredients } \\
\hline grass silage & 21.45 & 22.03 & 22.65 & 22.53 \\
\hline maize silage & 26.07 & 26.29 & 26.97 & 26.31 \\
\hline brewer's grain & 11.04 & 11.31 & 11.18 & 11.15 \\
\hline barley flacks & 23.19 & 21.01 & 18.64 & 17.36 \\
\hline wheat flacks & 7.65 & 7.38 & 7.12 & 7.21 \\
\hline rapeseed oilmeal & 8.42 & 7.96 & 7.72 & 7.82 \\
\hline Ca-FA salt ${ }^{1}$ & - & 1.84 & 3.54 & 5.40 \\
\hline limestone & 0.80 & 0.82 & 0.84 & 0.87 \\
\hline dicalcium phosphate & 0.60 & 0.60 & 0.60 & 0.60 \\
\hline salt & 0.20 & 0.20 & 0.20 & 0.20 \\
\hline mineral-vitamin premix ${ }^{2}$ & 0.58 & 0.56 & 0.54 & 0.55 \\
\hline \multicolumn{5}{|l|}{ Chemical composition } \\
\hline dry matter, $\%$ & 65.43 & 65.67 & 65.88 & 66.04 \\
\hline crude protein & 15.55 & 15.42 & 15.41 & 15.41 \\
\hline RUP', \% CP & 31.21 & 30.98 & 30.44 & 30.01 \\
\hline ether extract & 2.57 & 4.52 & 7.29 & 9.35 \\
\hline $\mathrm{NDF}$ & 31.21 & 29.95 & 29.74 & 30.44 \\
\hline $\mathrm{ADF}$ & 19.57 & 18.15 & 18.08 & 18.05 \\
\hline ash & 8.80 & 8.90 & 8.94 & 8.99 \\
\hline $\mathrm{Ca}$ & 0.85 & 0.89 & 0.91 & 0.94 \\
\hline $\mathrm{P}$ & 0.44 & 0.42 & 0.43 & 0.40 \\
\hline $\mathrm{Mg}$ & 0.29 & 0.30 & 0.28 & 0.27 \\
\hline $\mathrm{NF}_{1}, \mathrm{Mcal} / \mathrm{kg}$ & 1.73 & 1.76 & 1.83 & 1.89 \\
\hline
\end{tabular}

${ }^{1}$ fatty acid composition of Ca-FA salts, g/100 g: SFA, 12.31; UFA, 87.69; MUFA, 30.94; PUFA, 56.75; PUFA-6, 22.50; PUFA-3, 33.71

${ }^{2}$ contained vit.: A 2500000 IU; D 650000 IU, E 400 IU per kg

${ }^{3}$ estimated from NRC (2001) 


\section{Samples and chemical analyses}

Milk yields were monitored and milk samples taken using a Mini F.V. Milkometer (Tru-Test Distributors Ltd., New Zealand). Milk for fat and protein analyses was preserved with 2-bromo-2-nitro-1,3-propanediol (Gropol) and frozen until analysis. Milk for the determination of fatty acids was preserved with a penicillin supplement and frozen. Milk characteristics, including acidity, density and specific weight, were determined in fresh milk from both milkings on the last day of each period.

Random samples of feeds for chemical analyses were collected during the last 3 days of each experimental period, then a representative sample was taken. The dry matter, basic nutrient, calcium and phosphorus content of the feeds was determined according to AOAC (1994). Dry matter was assayed at $105^{\circ} \mathrm{C}$, and the dry mater content of silages was adjusted for the level of volatile substances (Brzóska et al., 1999). The nutritive value of the feeds and diets was calculated using WINWAR software. The NDF and ADF contents were determined according to the method of Goering and Van Soest (1970). Calcium and phosphorus were determined after mineralization of the samples in a mixture of nitric and perchloric acids, performed in a MEGA 1300 microwave oven in teflon dishes, calcium was assayed using atomic absorption spectroscopy (AAS; Philips; PU 9400), and phosphorus was determined colorimetrically (Polish Standard, 1976). The fat and protein content of milk was determined by infrared spectroscopy using a MilkoSkan FT 120 apparatus (Foss-Electric). Milk acidity, density and specific gravity were determined according to Polish Standards (1968). The nitrogen fraction (Table 3) in milk was determined according to Gordon and Kolan (1983). Milk fatty acids were estimated as methyl esters according to Atwal et al. (1990) the method, using a gas chromatograph (GC Varian 3400) and a CP-Wax 58 column (60 m; $0.53 \mathrm{MT} ; 1.0$ micron). Fatty acids were extracted using the Folch et al. (1956) method. To calculate the amount of fatty acids in milk, it was assumed on the basis of the studies performed by Schauff and Clark (1992) that glycerol represents $120.9 \mathrm{~g} / \mathrm{kg}$ of milk fat.

At the end of each period and after the morning feeding, blood samples were taken from the jugular vein into heparinizied tubes and centrifuged to separate plasma. Glucose was determined in blood plasma within $2 \mathrm{~h}$ of collection, and the other analyses of the samples were performed after thawing of frozen samples. The plasma glucose, total protein, triglycerides, total cholesterol and high-density lipoprotein (HDL) contents were determined enzymatically using standard diagnostic tests (Cormay Diagnostyka, Poland).

The milk yield of the cows was corrected for fat (4.0\%) and protein $(3.2 \%)$, and the intake of net energy (NEL) and protein digestible in the intestine (PDI) 
were calculated. The efficiency of milk production and the PDI to NEL ratio were calculated using regression equations provided by Subnel et al. (1994).

The results were analysed statistically with analysis of variance and the new multiple range test (Tukey test) using Statgraphics 6.0 software.

\section{RESULTS}

The CSFA used in the study contained $87.69 \mathrm{~g} / 100 \mathrm{~g}$ of UFA (including $30.94 \mathrm{~g}$ of MUFA) and $56.75 \mathrm{~g}$ of PUFA (including $33.6 \mathrm{~g}$ of $\mathrm{n}-3$ linoleic acid). The intake of ration dry matter did not differ significantly among the groups (Table 2). The milk yield of the cows averaged $27.2 \pm 0.55 \mathrm{~kg} /$ day and, like the amount of fat- and protein-corrected milk, did not differ significantly between the groups. Giving CSFA to cows significantly increased the fat content of milk

Table 2. Feeds intake, milk yield and milk nutrients content

\begin{tabular}{|c|c|c|c|c|c|}
\hline \multirow{2}{*}{ Item } & \multicolumn{4}{|c|}{ Ca-FA salts, $\%$ diet DM } & \multirow{2}{*}{ SE } \\
\hline & 0.00 & 1.84 & 3.54 & 5.40 & \\
\hline \multicolumn{6}{|l|}{ Feed intake, $\mathrm{kg} \mathrm{DM/d}$} \\
\hline total & 17.57 & 17.16 & 17.35 & 17.40 & 0.35 \\
\hline grass silage & 3.77 & 3.78 & 3.93 & 3.92 & 0.11 \\
\hline maize silage & 4.58 & 4.60 & 4.79 & 4.73 & 0.08 \\
\hline brewer's grain & 1.94 & 1.94 & 1.94 & 1.94 & 0.01 \\
\hline concentrate mixture & 7.28 & 6.84 & 6.69 & 6.81 & 0.41 \\
\hline \multicolumn{6}{|l|}{ Milk production } \\
\hline milk, kg/d & 27.1 & 27.8 & 27.0 & 26.9 & 0.55 \\
\hline $\mathrm{FPCM}^{1}, \mathrm{~kg} / \mathrm{d}$ & 24.9 & 25.9 & 25.1 & 25.4 & 0.52 \\
\hline fat, $\%$ & $3.35^{\mathrm{Cc}}$ & $3.46^{\mathrm{Bb}}$ & $3.55^{\mathrm{Bb}}$ & $3.77^{\mathrm{Aa}}$ & 0.10 \\
\hline fat, $g / d$ & $908^{\mathrm{Cc}}$ & $962^{\mathrm{Bb}}$ & $959^{\mathrm{Bb}}$ & $1014^{\mathrm{Aa}}$ & 17 \\
\hline protein, $\%$ & $3.29^{\mathrm{Aa}}$ & $3.34^{\mathrm{Aa}}$ & $3.12^{\mathrm{Bb}}$ & $2.98^{\mathrm{Cc}}$ & 0.06 \\
\hline protein, $g / d$ & $892^{\mathrm{Aa}}$ & $929^{\mathrm{Aa}}$ & $842^{\mathrm{Bb}}$ & $802^{\mathrm{Cc}}$ & 21 \\
\hline lactose. $\%$ & 4.85 & 4.86 & 4.82 & 4.84 & 0.01 \\
\hline lactose, $\mathrm{g} / \mathrm{d}$ & 1314 & 1351 & 1301 & 1302 & 31 \\
\hline $\mathrm{SNF}, \%$ & 8.86 & 8.90 & 8.87 & 8.86 & 0.23 \\
\hline SNF, g/d' & 2401 & 2474 & 2395 & 2383 & 52 \\
\hline acidity, ${ }^{\circ} \mathrm{SH}$ & 6.18 & 6.18 & 6.05 & 6.13 & 0.06 \\
\hline renneting time, sec. & 173 & 169 & 178 & 174 & 9 \\
\hline density, $\mathrm{g} / \mathrm{cm}^{3}$ & 1.030 & 1.030 & 1.048 & 1.030 & 0.004 \\
\hline \multicolumn{6}{|l|}{ Cow's liveweight $/ \mathrm{kg}$} \\
\hline before experiment & 524 & 575 & 573 & 537 & 14 \\
\hline after experiment & 520 & 578 & 581 & 544 & 15 \\
\hline BW change, g/day & -48 & +36 & +95 & +83 & 1.8 \\
\hline
\end{tabular}

${ }^{1}$ fat and protein corrected milk (Subnel et al., 1994); ${ }^{2}$ free fat dry matter; ${ }^{3}$ body mass: values in the same rows with different letters are differ signitcantly a,b,c $-\mathrm{P}<0.05,{ }^{\mathrm{A}, \mathrm{B}, \mathrm{C}}-\mathrm{P}<0.01$ 
and daily production of fat $(\mathrm{P}<0.01)$ and significantly deceased the protein content of milk and daily protein production to below the control group level $(\mathrm{P}<0.01)$. No significant differences were found in the level or yield of lactose or solids-not-fat (SNF) in milk. Dietary CSFA did not have a significant effect on the physico-chemical properties of milk such as acidity, renneting time, and density. The increasing intake of CSFA was accompanied by a decrease in the $\mathrm{N}$-total of milk with significant differences between the groups $(\mathrm{P}<0.01)$. The N-protein and N-casein content of milk decreased significantly; there was a downward tendency in the percentage of these fractions in relation to the $\mathrm{N}$-total content of milk (Table 3).

Table 3. N-fraction in milk $\mathrm{g} / 1000 \mathrm{ml}$

\begin{tabular}{llllll}
\hline \multirow{2}{*}{ Item } & \multicolumn{3}{c}{ Ca-FA salts, \% diet DM } & \multirow{2}{*}{ SE } \\
\cline { 2 - 5 } & 0.00 & 1.84 & 3.54 & 5.40 & \\
\hline Total N & $5.15^{\mathrm{Aa}}$ & $5.23^{\mathrm{Aa}}$ & $4.89^{\mathrm{Bb}}$ & $4.67^{\mathrm{Bb}}$ & 0.06 \\
True-N protein & $4.84^{\mathrm{Aa}}$ & $4.86^{\mathrm{Aa}}$ & $4.54^{\mathrm{Bb}}$ & $4.34^{\mathrm{Bb}}$ & 0.07 \\
Casein N & $3.96^{\mathrm{a}}$ & $3.98^{\mathrm{a}}$ & $3.73^{\mathrm{b}}$ & $3.56^{\mathrm{b}}$ & 0.06 \\
Whey N & 0.88 & 0.88 & 0.81 & 0.78 & 0.02 \\
NPN & 0.31 & 0.37 & 0.35 & 0.33 & 0.01 \\
\hline
\end{tabular}

values in the same rows with different letters are differ significantly ${ }^{\mathrm{a}, \mathrm{b}}-\mathrm{P}<0.05$; ${ }^{\mathrm{A}, \mathrm{B}}-\mathrm{P}<0.01$

There were no differences in true protein, casein and NPN content, as \% of total $N$ (about 93, 76 and 6-7, respectively)

The increased level of CSFA in cow diets significantly reduced the level of SFA, including myristic and palmitic acids $(\mathrm{P}<0.01)$. Giving the cows CSFA from linseed oil significantly increased the daily synthesis of stearic acid $\left(\mathrm{C}_{18: 0}\right)$ and oleic acid $\left(\mathrm{C}_{18: 1}\right)$ in milk. There was also a significant increase in the production of $\mathrm{n}-3 \alpha$-linolenic acid $\left(\mathrm{C}_{18: 3}\right)(\mathrm{P}<0.01)$. An upward tendency was found in the level of CLA isomers, including that of cis-9 trans-11 CLA (Table 4). The level of $n=3$ PUFA in milk increased significantly (Table 4), corresponding to a significant increase $(\mathrm{P}<0.05)$ in the daily synthesis of PUFA (Table 5). Giving the cows CSFA significantly lowered the n-6-to-n-3 PUFA ratio $(\mathrm{P}<0.05)$. As a result of the changes described for a $0.0-5.4 \%$ range of dietary CSFA, UFA content increased by $69.4 \%$ and SFA synthesis decreased by $6.4 \%$. Daily synthesis of $n-3$ MUFA and PUFA increased significantly. As a result of giving CSFA to the cows, DFA content increased by $69.4 \%$ and the differences between the groups were significant $(\mathrm{P}<0.01)$ (Table 5). 
Table 4. Fatty acid composition of milk fat, g/100 g

\begin{tabular}{|c|c|c|c|c|c|}
\hline \multirow{2}{*}{ Item } & \multicolumn{4}{|c|}{ Ca-FA salts, $\%$ diet DM } & \multirow{2}{*}{ SE } \\
\hline & 0.00 & 1.84 & 3.54 & 5.40 & \\
\hline $\mathrm{C}_{8}$ & 4.84 & 4.60 & 4.44 & 4.51 & 0.18 \\
\hline $\mathrm{C}_{10}$ & 8.12 & 7.89 & 7.53 & 6.99 & 0.20 \\
\hline $\mathrm{C}_{12}$ & 7.18 & 7.01 & 6.48 & 5.20 & 0.44 \\
\hline $\mathrm{C}_{14}$ & $16.22^{\mathrm{Aa}}$ & $11.22^{\mathrm{Bb}}$ & $10.33^{\mathrm{Bb}}$ & $9.26^{\mathrm{Bb}}$ & 0.41 \\
\hline $\mathrm{C}_{16}$ & $35.75^{\mathrm{a}}$ & $32.88^{\mathrm{ab}}$ & $27.70^{\mathrm{b}}$ & $25.14^{\mathrm{b}}$ & 0.38 \\
\hline $\mathrm{C}_{16: 1}$ & 1.36 & 1.26 & 1.25 & 1.40 & 0.09 \\
\hline $\mathrm{C}_{18}$ & $7.92^{\mathrm{b}}$ & $8.90^{\mathrm{b}}$ & $11.41^{\mathrm{ab}}$ & $12.50^{\mathrm{a}}$ & 0.57 \\
\hline $\mathrm{C}_{18: 1}$ & $17.11^{\mathrm{Cc}}$ & $19.13^{\mathrm{Bb}}$ & $23.49^{\mathrm{AaBb}}$ & $27.56^{\mathrm{Aa}}$ & 1.81 \\
\hline $\mathrm{C}_{18: 2}$ & 33.06 & 4.11 & 3.49 & 3.20 & 0.13 \\
\hline $\mathrm{C}_{18: 3 \text { GAMMA }}$ & $0.04^{\mathrm{d}}$ & $0.08^{\mathrm{c}}$ & $0.14^{\mathrm{b}}$ & $0.18^{\mathrm{a}}$ & 0.07 \\
\hline $\mathrm{C}_{18: 3 \mathrm{ALFA}}$ & $0.84^{\mathrm{Cc}}$ & $1.15^{\mathrm{Cc}}$ & $1.69^{\mathrm{Bb}}$ & $2.19^{\text {Aa }}$ & 0.09 \\
\hline CLA & 1.32 & 1.53 & 1.62 & 1.52 & 0.11 \\
\hline CLA c9-t11 & 1.12 & 1.17 & 1.34 & 1.26 & 0.07 \\
\hline CLA t10-c12 & 0.05 & 0.07 & 0.07 & 0.06 & 0.002 \\
\hline CLA c9-c11 & 0.08 & 0.11 & 0.12 & 0.09 & 0.002 \\
\hline CLA t9-t11 & 0.07 & 0.09 & 0.09 & 0.11 & 0.002 \\
\hline $\mathrm{C}_{20}$ & 0.15 & 0.14 & 0.14 & 0.14 & 0.02 \\
\hline $\mathrm{C}_{20: 4}$ & 0.09 & 0.10 & 0.09 & 0.10 & 0.01 \\
\hline $\mathrm{C}_{20: 5} \mathrm{EPA}$ & 0.05 & 0.04 & 0.04 & 0.05 & 0.002 \\
\hline $\mathrm{C}_{22}$ & 0.05 & 0.05 & 0.05 & 0.05 & 0.002 \\
\hline $\mathrm{C}_{22: 1}$ & 0.01 & 0.00 & 0.02 & 0.00 & 0.002 \\
\hline $\mathrm{C}_{22: 6}$ DHA & 0.03 & 0.01 & 0.0 & 0.01 & 0.002 \\
\hline $\mathrm{SFA}^{1}$ & $76.09^{\mathrm{Aa}}$ & $72.69^{\mathrm{AaBb}}$ & $68.08^{\mathrm{Bb}}$ & $63.79^{\mathrm{Cc}}$ & 0.61 \\
\hline UFA & $23.9^{\mathrm{Cc}}$ & $27.31^{\mathrm{Bb}}$ & $31.92^{\mathrm{AaBb}}$ & $36.21^{\mathrm{Aa}}$ & 0.61 \\
\hline MUFA & $18.37^{\mathrm{Cc}}$ & $20.39^{\mathrm{cc}}$ & $24.76^{\mathrm{Bb}}$ & $28.96^{\mathrm{Aa}}$ & 0.50 \\
\hline PUFA & $5.39^{\mathrm{c}}$ & $6.92^{\mathrm{bc}}$ & $7.09^{b}$ & $7.25^{\mathrm{a}}$ & 0.11 \\
\hline PUFA-6 & 4.19 & 5.52 & 5.34 & 5.00 & 0.06 \\
\hline PUFA-3 & $1.20^{\mathrm{d}}$ & $1.40^{\mathrm{c}}$ & $1.75^{\mathrm{b}}$ & $2.25^{\mathrm{a}}$ & 0.02 \\
\hline DFA & $31.8^{\mathrm{d}}$ & $36.31^{\mathrm{c}}$ & $43.33^{\mathrm{b}}$ & $48.71^{\mathrm{a}}$ & 0.65 \\
\hline OFA & $68.17^{\mathrm{a}}$ & $63.69^{\mathrm{b}}$ & $56.67^{\mathrm{c}}$ & $51.29^{\mathrm{d}}$ & 0.65 \\
\hline UFA/SFA & $0.314^{\mathrm{d}}$ & $0.375^{\mathrm{c}}$ & $0.468^{\mathrm{b}}$ & $0.568^{\mathrm{a}}$ & 0.012 \\
\hline DFA/OFA & $0.467^{\mathrm{d}}$ & $0.570^{\mathrm{c}}$ & $0.765^{\mathrm{b}}$ & $0.950^{\mathrm{a}}$ & 0.027 \\
\hline MUF'A/SFA & $0.241^{\mathrm{d}}$ & $0.281^{\mathrm{c}}$ & $0.364^{\mathrm{b}}$ & $0.454^{\mathrm{a}}$ & 0.017 \\
\hline PUFA!SFA & $0.071^{\mathrm{c}}$ & $0.095^{\mathrm{bc}}$ & $0.104^{\mathrm{ab}}$ & $0.114^{\mathrm{a}}$ & 0.009 \\
\hline PUFA 613 & $3.492^{b}$ & $3.943^{\mathrm{a}}$ & $3.051^{\mathrm{c}}$ & $2.222^{\mathrm{d}}$ & 0.093 \\
\hline
\end{tabular}

values in the same rows with different letters are differ significantly a,b,c,d $-\mathrm{P}<0.05$; ${ }^{\mathrm{A}, \mathrm{B}, \mathrm{C}}$ - values in the same rows with different letters are differ significantly $(\mathrm{P}<0.01)$

${ }^{1}$ SFA - saturated fatty acids; UFA - unsaturated fatty acids; MUFA - monounsaturated fatty acids: PUFA- polyunsaturated fatty acids; PUFA-6-polyunsaturated fatty acids family n-6 acids; PUFA-3 -polyunsaturated fatty acids family n-3 acids; DFA - desirable fatty acids (unsaturated $+\mathrm{C}_{18: 0}$ ); OFA - undesirable fatty acids (saturated) 
Table 5. Calculated yields of milk fatty acid, g/d

\begin{tabular}{|c|c|c|c|c|c|}
\hline \multirow{2}{*}{ Item } & \multicolumn{4}{|c|}{ Ca-FA salts, $\%$ diet DM } & \multirow{2}{*}{ SE } \\
\hline & 0.00 & 1.84 & 3.54 & 5.40 & \\
\hline$\overline{\mathrm{C}_{8}}$ & 38.6 & 38.9 & 37.4 & 40.2 & 0.08 \\
\hline $\mathrm{C}_{10}$ & 64.8 & 66.7 & 63.5 & 62.3 & 0.09 \\
\hline $\mathrm{C}_{12}$ & 57.3 & 59.3 & 54.6 & 46.4 & 0.07 \\
\hline $\mathrm{C}_{14}$ & $129.4^{\mathrm{Aa}}$ & $94.9^{\mathrm{Bb}}$ & $87.1^{\mathrm{Cc}}$ & $82.5^{\mathrm{Cc}}$ & 0.10 \\
\hline $\mathrm{C}_{16}$ & $285.3^{\text {Aa }}$ & $278.1^{\text {Aa }}$ & $233.5^{\mathrm{Bb}}$ & $224.1^{\mathrm{Bb}}$ & 0.24 \\
\hline $\mathrm{C}_{16: 1}$ & 10.9 & 10.7 & 10.5 & 12.5 & 0.04 \\
\hline $\mathrm{C}_{18}$ & $63.2^{\mathrm{Dd}}$ & $75.3^{\mathrm{Cc}}$ & $96.2^{\mathrm{Bb}}$ & $111.4^{\mathrm{Aa}}$ & 0.13 \\
\hline $\mathrm{C}_{18: 1}$ & $136.6^{\mathrm{Dd}}$ & $161.8^{\mathrm{Cc}}$ & $198.0^{\mathrm{Bb}}$ & $245.7^{\text {Аa }}$ & 0.27 \\
\hline $\mathrm{C}_{18: 2}$ & 24.4 & 34.8 & 29.4 & 28.5 & 0.05 \\
\hline $\mathrm{C}_{18: 3 \text { GAMMA }}$ & 0.4 & 0.7 & 1.2 & 1.6 & 0.0 \\
\hline $\mathrm{C}_{18: 3 \mathrm{ALFA}}$ & $6.7^{\mathrm{Cc}}$ & $12.7^{\mathrm{Bb}}$ & $14.2^{\mathrm{Bb}}$ & $19.5^{\text {Aa }}$ & 0.03 \\
\hline CLA & 10.5 & 12.9 & 13.7 & 13.5 & 0.03 \\
\hline CLA c9-t11 & 9.0 & 9.9 & 11.3 & 11.2 & 0.03 \\
\hline CLA t10-c12 & 1.2 & 1.2 & 1.2 & 1.2 & 0.01 \\
\hline CLA c9-c11 & 0.7 & 0.8 & 0.8 & 0.9 & 0.0 \\
\hline CLA t9-t11 & 0.4 & 0.3 & 0.3 & 0.4 & 0.0 \\
\hline $\mathrm{C}_{20}$ & 0.4 & 0.4 & 0.4 & 0.4 & 0.0 \\
\hline $\mathrm{C}_{20: 4}$ & 0.1 & 0.0 & 0.2 & 0.0 & 0.0 \\
\hline $\mathrm{C}_{20: 5} \mathrm{EPA}$ & 0.3 & 0.1 & 0.2 & 0.1 & 0.0 \\
\hline $\mathrm{C}_{22}$ & $607.4^{\mathrm{Aa}}$ & $614.7^{\text {Aa }}$ & $574.0^{\mathrm{Bb}}$ & $568.6^{\mathrm{Bb}}$ & 23.22 \\
\hline $\mathrm{C}_{22: 1}$ & $190.6^{\text {Dd }}$ & $231.0^{\mathrm{Cc}}$ & $269.1^{\mathrm{Bb}}$ & $322.8^{\mathrm{Aa}}$ & 19.88 \\
\hline $\mathrm{C}_{22: 6}$ DHA & $146.6^{\mathrm{Dd}}$ & $172.4^{\mathrm{Cc}}$ & $208.8^{\mathrm{Bb}}$ & $258.1^{\mathrm{Aa}}$ & 18.12 \\
\hline SFA $^{1}$ & $44.0^{\mathrm{c}}$ & $58.5^{\mathrm{b}}$ & $59.8^{\mathrm{b}}$ & $64.6^{\mathrm{a}}$ & 0.19 \\
\hline UFA & 33.4 & 46.7 & 45.0 & 44.6 & 0.08 \\
\hline MUFA & $9.6^{\mathrm{c}}$ & $11.8^{\mathrm{c}}$ & $14.8^{\mathrm{b}}$ & $20.1^{\mathrm{a}}$ & 0.04 \\
\hline PUFA & $254.0^{\mathrm{Dd}}$ & $307.1^{\mathrm{Cc}}$ & $365.3^{\mathrm{Bb}}$ & $434.2^{\mathrm{Aa}}$ & 21.11 \\
\hline PUFA-6 & $544.0^{\mathrm{Aa}}$ & $538.6^{\mathrm{Aa}}$ & $477.8^{\mathrm{Bb}}$ & $457.2^{\mathrm{Bb}}$ & 22.00 \\
\hline
\end{tabular}

- values in the same rows with different letters are differ significantly a,b,c,d - $\mathrm{P}<0.05$;

$\mathrm{A}, \mathrm{B}, \mathrm{C}, \mathrm{D}-\mathrm{P}<0.01 ;{ }^{1}$ explanation see Table 4

Giving the cows CSFA from linseed oil significantly increased the plasma concentration of triglycerides $(\mathrm{P}<0.05)$, while significantly decreasing the level of total cholesterol and HDL cholesterol $(\mathrm{P}<0.01)$. No significant differences were found in the levels of glucose, total protein, urea, or LDL cholesterol (Table 6). 
Table 6. Metabolite concentration in blood plasma, $\mathrm{mg} / 100 \mathrm{ml}$

\begin{tabular}{|c|c|c|c|c|c|}
\hline \multirow{2}{*}{ Item } & \multicolumn{4}{|c|}{ Ca-FA salts, $\%$ diet DM } & \multirow{2}{*}{ SE } \\
\hline & 0.00 & 1.84 & 3.54 & 5.40 & \\
\hline Glucose & 55.20 & 56.48 & 56.99 & 55.44 & 1.88 \\
\hline Total protein & 7.48 & 7.71 & 7.79 & 7.77 & 0.14 \\
\hline Urea & 21.10 & 20.18 & 20.09 & 22.64 & 0.89 \\
\hline Triglycerols & $8.43^{\mathrm{c}}$ & $9.63^{\mathrm{b}}$ & $10.38^{\mathrm{ab}}$ & $11.15^{\mathrm{a}}$ & 0.75 \\
\hline Total cholesterol & $220.86^{\text {Aa }}$ & $212.59^{\mathrm{Bb}}$ & $201.07^{\mathrm{Cc}}$ & $199.66^{\mathrm{Cc}}$ & 12.33 \\
\hline HDI & $184.52^{\mathrm{Aa}}$ & $176.44^{\mathrm{AaBb}}$ & $170.32^{\mathrm{Bb}}$ & $168.86^{\mathrm{BbCc}}$ & 6.99 \\
\hline LDL & 32.66 & 34.43 & 28.49 & 29.24 & 4.70 \\
\hline
\end{tabular}

valuea in the same rows with different letters are differ significantly a.b,c $-\mathrm{P}<0.05$; ${ }^{\mathrm{A}, \mathrm{B}, \mathrm{C}}$ - $\mathrm{P}<0.01$

\section{DISCUSSION}

The efficiency of plant oils and CSFA in cow nutrition has been addressed in a number of studies (e.g., Hagemeister et al., 1988; Aii et al., 1991; Nowak and Potkański, 1997; Brzóska et al., 1999). CSFA obtained from linseed oil carry a large load of UFA, including n-3 UFA. Giving cows vegetable oils results in approximately $80 \%$ of UFA being hydrogenated to SFA (Guczyńska, 1999), which limits the scope for modification of milk fatty acid composition. The advantage of CSFA over vegetable oils is their low solubility in the rumen fluid.

The literature concerning the effect of CSFA on dairy cows is inconclusive and inconsistent as regards to how they affect dry matter intake. Some authors have reported that cows receiving dietary supplements responded with lower dry matter intake, while in other studies, this reaction did not occur (Kennelly, 1996). The decreased dry matter intake from rations containing fodder fat may be attributed to their higher energy concentration, which at an average intake of dry matter can exceed the daily energy requirement of the cows.

The use of CSFA as a dietary source of highly concentrated energy that has no negative effects on cows has opened new prospects. Results concerning the effects of CSFA on milk yield, fat and protein production in milk are, however, inconsistent. The findings of the present study show that the dry matter intake and milk yield of the cows did not significantly differ as a result of giving linseed-oil CSFA at a rate of $0.0-5.6 \%$ of ration dry matter, corresponding to a daily intake of 0 to $960 \mathrm{~g}$. Despite the increased energy concentration of the diet, the milk yield of the cows remained at a similar level and did not differ significantly among the groups. Different findings were reported by Nowak and Potkański (1997), who gave cows up to $15 \%$ CSFA in feed mixture. The prevailing opinion is, however, that the milk yield of cows is not significantly differentiated by the type, form or amount of fodder fat. Chouinard et al. (1997), who gave cows with an average 
yield of $34.5 \mathrm{~kg}$ milk/day, rations containing 2 or $4 \%$ (447 or $894 \mathrm{~g} /$ day) CSFA from canola oil, did not find significant differences in the milk yield, only a slight downward tendency. In later studies, Romo et al. (2000) found that the milk yield of cows is significantly differentiated not by the amount of fodder fat, but by the geometric form of the fatty acids. By giving duodenal infusions of cis-type acids compared with trans acids, they increased their yield by about $4 \mathrm{~kg}$ of milk, with an increase in milk fat of 0.18 pcrcentage units and a decrease in milk protein of 0.24 percentage units.

Traditional sources of fat are a mixture of fatty acids with cis and trans geometric configurations. In the research conducted so far, cis fatty acids have been the main object of study in addition to the rumen synthesis of CLA C18:2 (Abuhazaleh et al., 2002; Brzóska, 2005).

In the present study, giving cows CSFA with a high level of UFA, modified milk composition by significantly increasing milk fat and decreasing milk protein. Daily production of fat increased significantly, whereas daily synthesis of protein decreased. In the above study by Chouinard et al. (1997), milk fat and protein levels decreased, as did their daily synthesis. Rodriguez et al. (1997), who fed cows of two breeds diets supplemented with CSFA from palm oil (Megalac) with different amounts of ruminally undegradable protein ( 29 vs $41 \%$ RUP), obtained an increase in the milk yield of Holstein and Jersey cows of approximately $2 \mathrm{~kg}$ milk on average, with inconsistent results concerning the fat and protein content of milk depending on the breed; the diurnal fat synthesis remained stable in Holsteins cows whereas increased significantly in Jerseys.

Most studies have found that dietary fat supplements, by increasing the amount of fat or leaving it unchanged, decrease the protein content, especially when the fat supplements in the diet exceed 2-2.5\% of dry matter (Wu et al., 1994; Brzóska et al., 1999). Similar results were obtained after duodenal infusion of fatty acids (Romo et al., 2000). In some studies, such infusion was accompanied by a decrease in the N-casein fraction of milk (DePeters et al., 1989). The decrease in the protein and $\mathrm{N}$-casein content of the milk of cows receiving a dietary fat supplement has not been explained, although several hypotheses have been proposed (e.g., DePeters and Cant, 1992; Wu et al., 1994). Wu et al. (1994), on the basis of a review of research findings, suggest that the decrease in milk protein can be attributed in part to the increased milk yield of the cows, and in part to the insufficient availability of amino acids in the mammary gland for increasing milk production stimulated by the dietary fat supplement. They also believe that increasing the absorption of amino acids that limit milk protein synthesis, either by adding amino acids or by increasing synthesis of microbiological protein in the rumen, may help to prevent the reduction in milk protein in cows receiving a dietary fat supplement. Adecrease in milk protein was also observed when the cows 
did not react to a dietary fat supplement with increased milk yield (Bines et al., 1978; DePeters and Palmquist, 1990). Casper and Schingoethe (1989) suggested that the increased concentration of fatty acids in the plasma of cows receiving a fat supplement may lower the release of somatotropin from the anterior lobe of the pituitary. They also suggested that somatotropin and insulin have a synergic effect on the control of amino acid uptake by the mammary gland. A decrease in the concentration of serum somatotropin can reduce the uptake of amino acids from blood and thus, milk protein synthesis. The decrease in the protein content of the milk of cows receiving a fat supplement is an important factor preventing the widespread application of this procedure to feeding cows.

No significant differences were found in the content or yield of lactose or solids-not-fat (SNF) in milk. Dietary CSFA did not have a significant effect on the physico-chemical properties of milk such as acidity, renneting time, and density. It can, therefore, be concluded that giving cows CSFA does not affect the physical properties of milk, although it can reduce the efficiency of cheese production due to the decreasing $\mathrm{N}$-casein content of milk with the addition of dietary fat.

The results of our study have shown that giving cows CSFA significantly increases the UFA content of milk. This mainly concerns medium-chain fatty acids with 18 carbon atoms, including those with one and three unsaturated bonds. The levels of stearic $\left(\mathrm{C}_{18: 0}\right)$ and oleic acids $\left(\mathrm{C}_{18: 1}\right)$ increased in milk to the largest extent. Stearic acid is considered to be neutral to human health. At the same time, a significant decrease in the level of saturated acids in milk, in particular myristic and palmitic acids, has been observed. These findings are reflected in the results of many studies, including those by Aii et al. (1991), Grimmer (1991) and Mansbridge and Blake (1996). Aii et al. (1991), who gave lactating cows CSFA from linseed oil ( 0 to $500 \mathrm{~g}$ /day), found the level of $\alpha$-linolenic acid in milk to increase from 0.49 to $1.95 \%$. In our study, this increase was $0.84-2.19 \%$ for the $0.00-5.40 \%$ range of CSFA. Aii et al. (1991) reported that under standard feeding conditions, the level of $\alpha$-linolenic acid in cow's milk is approximately $0.4-0.5 \%$, while the proportion of acid transferred to milk from the diet containing linseed oil CSFA is around $5 \%$. Calculations from our study indicate that the value of this parameter was $4.4 \%$ for cows receiving $960 \mathrm{~g} /$ day of CSFA. In our study, giving cows CSFA from linseed oil at 0-960 g/day resulted in an increase in $\mathrm{n}-3$ PUFA in milk from 1.2 to $2.25 \mathrm{~g} / 100$, and an increase in synthesis from 9.6 to $20.1 \mathrm{~g} /$ day. For a consumer eating $5 \mathrm{~g}$ of butter per day this translates into an estimated increase in the intake of n-3 acids from butter from 53 to $99 \mathrm{mg} /$ day. It is assumed that a total dietary intake of $100-200 \mathrm{mg} /$ day of n-3 PUFA can be a factor limiting the incidence of coronary thrombosis (DOH, 1994). The obtained increase thus significant. Also of significance in this disease is the ratio of n-6 to n-3 PUFA (Sargent, 1997). It was found that giving cows CSFA from linseed oil 
drastically reduces the n- 6 to $n-3$ ratio in milk from around 3.5:1 in the control group to $2.2: 1$ in the group receiving 5.4\% CSFA in the diet. From the viewpoint of the health-promoting value of milk fat, this change in the composition of fatty acids is considered positive.

During our experiment, cows were in the final part of the highest milk yield period. The fluctuations in their body weight reflect the metabolic process of lipolysis in the control group and the process of lipogenesis in the experimental groups. The average body weight of the cows showed a slight upward tendency, possibly suggesting that they might have undergone lipogenesis, which occurs in cows during the period after the peak of lactation when they start to restore the fatty tissue and body weight lost during lactation. The data obtained indicate that giving cows 316,614 or $940 \mathrm{~g}$ of CSFA results in a surplus of dietary energy intake compared with the energy secreted in milk, leading to increased body weight. The reaction of cows to the source of dietary fat is a typical response confirmed in many experiments using CSFA in dairy cow nutrition (Aii et al., 1991; Chouinard et al., 1997; Brzóska et al., 1999). Analysis of the cows' plasma showed a typical reaction to the supplement of unsaturated dietary fat, consisting in a significant increase in the level of plasma triglycerides and a decrease in the levels of total and HDL cholesterol.

\section{CONCLUSIONS}

It is concluded that giving cows in mid-lactation CSFA from linseed oil containing high levels of n-3 acids $(316,614$ or $940 \mathrm{~g}$ /day) leads to a significant increase in milk UFA and a decrease in milk SFA. This increase in milk UFA and synthesis concerns stearic (C18), oleic (C18:1) and $\alpha$-linolenic acids (C18:3). As a result of the described changes in the proportion and synthesis of fatty acids, there is an increase in the DFA acid content of milk and the daily synthesis of these acids, with an improved ratio of n- 6 to n-3 PUFA. Giving cows CSFA from linseed oil at $0.0-5.40 \%$ of the ration dry matter does not significantly change their milk yield, increases the fat content of milk and daily production of fat, and decreases the protein content of milk and daily production of protein. Other chemical and physical propcrties of milk are not changed significantly. CSFA from linseed oil can be considered a feed factor that considerably increases the dietetic value of milk.

\section{ACKNOWLEDGEMENTS}

The author wishes to thank Henryk Żywczok, PhD, for selecting and carring for the animals, taking samples of feeds and milk. The author also wishes to thank 
employees of the Central Laboratory of the National Research Institute of Animal Production, Marta Szczypuła, M.Sc., Krystyna Sala, Ph.D., Marek Kryszczak, M.Sc., Alicja Sobczyk and Zdzisław Czmer for performing the analyses of feeds and milk.

\section{REFERENCES}

Abuhazaleh A.A., Schingoethe D.J., Hippen A.R., Kalscheur K.F., 2002. Feeding fish meal and extruded soybeans enhances the conjugated linoleic acid (CLA) content of milk. J. Dairy Sci. 85, 624-631

Aii T., Kurihara M., Ishida S., 1991. Increase in alpha-linolenic acid in milk fat by feeding the calcium soap of fatty acid prepared from linseed oil. Anim. Feed Sci. Tech. 62, 58-62

AOAC, 1994. Association of Official Analytical Chemists, Official Methods of Analysis. $15^{\text {th }}$ Edition. Washington, DC

Atwal A.S., Hidiroglou M., Kramer J.K.G., Binns M.R., 1990. Manipulation of the fatty acids composition of milk by feeding protected canola seeds. J. Dairy Sci. 75, 1090-1096

Bartnikowska E., Kulasek G., 1994. Importance of unsaturated fatty acids in human and animal nutrition. Second Part (in Polish). Med. wet. 50, 34-38

Bines J.A., Brumby P.E., Storry J.E., Fulford R.J., Braithwaite G.D., 1978. The effect of protected lipids on nutrient intakes, blood and rumen metabolites and milk secretion in dairy cows during early lactation. J. Agr. Sci. 91, 135-150

Brzóska F., 2005. Effect of dietary vegetable oils on milk yield, composition and CLA isomer profile in milk from dairy cows. J. Anim. Feed Sci. 14, 445-459

Brzóska F., Gąsior R., Sala K., Zyzak W., 1999. Effect of linseed oil fatty acid calcium salts and vitamin C; on milk yield and composition. J. Anim. Feed Sci. 8, 367-378

Casper D.P., Schingoethe D.J., 1989. Model to describe and alleviate milk protein depression in early lactation cows fed a high fat diet. J. Dairy Sci. 72, 3327-3335

Chouinard P.Y., Girard V., Brisson G.J., 1997. Lactational response of cows to different concentration of calcium salts of canola oil fatty acids with or without bicarbonates. J. Dairy Sci. 80, 11851193

Department of Health, UK, 1994. Nutritional Aspects of Cardiovascular Disease. Report of the Cardiovascular Review Group Committee on Medical Aspects of Food Policy. Department of Health Report on Health and Social Subject No. 46, London (UK), HMSO

DePeters E.T., Cant J.P., 1992. Nutritional factors influencing the nitrogen composition of bovine milk: A review. J. Dairy Sci. 75, 2043-2070

DePeters E.J., Palmquist D.L., 1990. Effect of fish meal and calcium salts of long-chain fatty acids on the nitrogen content of milk. J. Dairy Sci. 73, Suppl., 242 (Abstr.)

DePeters E.T., Taylor S.J., Baldwin R.L., 1989. Effect of dietary fat in isocaloric rations on the nitrogen content of milk from Holstein cows. J. Dairy Sci. 72, 2949-2957

Folch J., Lees M., Sloane-Stanley G.H., 1956. A simple method for the isolation and purification of total lipids from animal tissues. J. Biol. Chem. 226, 497-509

Givens D.I., Cottrill B.R., Davies M., Lee P.A., Mansbridge R.J., Moss A.R., 2000. Sources of n-3 polyunsaturated fatty acids additional to fish oil for livestock diets - a review. Nutr. Abstr. Rev., Ser. B 70, 1-20

Goering H.R., van Soest P.J., 1970. Forage Fiber Analysis. Agriculture Handbook, No. 379. USDA, Washington 
Gordon W.G., Kolan E.B., 1983. Protein in milk. In: B.W. Webb, A.H. Johnson, J.A. Alford (Editors). Fundamentals of Dairy Chemistry. 2nd Edition. AVI Publ. Co., Inc., West Port, CT, pp. 78

Grimmer R.R., 1991. Effect of feed on the composition of milk fat. J. Dairy Sci. 74, 3244-3257

Guczyńska W., 1999. Lipid metabolism in the rumen (in Polish). Post. Nauk. rol. 46 (1), 71-80

Hagemeister H., Precht D., Barth C.A., 1988. Studies on transfer of omega-3 fatty acids into bovine milk fat. Milchwissenschaft 43, 153-158

Mansbridge R.I., Blake J.S., 1996. Nutritional factors affecting the fatty acid composition of bovine milk. In: D.I. Givens (Editor). Fats in the Diet of Animals and Man. Proceedings of ADAS Conference, NEC, Birmingham

Mansbridge R.I., Blake J.S., 1997. Nutritional factors affecting the fatty acid composition of bovine milk. Brit. J. Nutr. 78, Suppl. 1, S37-S47

Nowak W., Potkański A., 1997. Effect of supplementing calcium soaps with maize and alfa-silage based diets on milk yield and composition (in Polish). Rocz. Nauk. Zoot. 24 (3), 119-129

Polish Standards, 1968. Milk. Research methods (in Polish). Edited by Polish Committee of Standardization, Warsaw

Polish Standards, 1976. PN-76/R-64781. Feeds. Phosphorus estimation (in Polish). Edited by Polish Committee of Standardization, Warsaw

Rodriguez L.A., Stallings C.C., Herbein J.H., McGilliard M.L., 1997. Effect of degradability of dietary protein and fat on ruminal, blood, and milk components of Jersey and Holstein cows. J. Dairy Sci. 80, 353-363

Romo G.A., Erdman R.A., Teter B.B., Sampugna J., Casper D.P., 2000. Milk composition and apparent digestibilities of dietary fatty acids in lactacing dairy cows abomasally infused with $c i s$ or trans fatty acids. J. Dairy Sci. 83, 2609-2619

Sargent J.R., 1997. Fish oil and human diet. Brit. J. Nutr. 78, Suppl. 1, S5-S13

Schauff D.J., Clark J.H., 1992. Effects of feeding diets containing calcium salts of long-chain fatty acids to lactating dairy cows. J. Dairy Sci. 75, 2990-3002

Subnel A.P.J., Meijer R.G.M., Van Straalen W.M., Tamminga S., 1994. Efficiency of milk protein production in the DVE protein evaluation system. Livest. Prod. Sci. 40, 215-224

Wu Z., Huber J.T., 1994. Relationship between dietary fat supplementation and milk protein concentration in lactating cows: A review. Livest. Prod. Sci. 39, 141-155

Wu Z., Huber J.T., Chan S.C., Simas J.M., Chen K.H., Varela J.G., Santos F., Fontes C., Yu P., 1994. Effect of source and amount of supplemental fat on lactation and digestion in cows. J. Dairy Sci. 77, 1644-1651 